CORRECTION

\title{
Correction to: Amino acid metabolism and signalling pathways: potential targets in the control of infection and immunity
}

\author{
Daniel Tomé iD \\ (c) The Author(s) 2021 \\ European Journal of Clinical Nutrition (2021) 75:1418; https://doi.org/10.1038/s41430-021-00979-2
}

Correction to: European Journal of Clinical Nutrition https://doi.org/ 10.1038/s41430-021-00943-0.

The original version of this article unfortunately contained a mistake in the abstract. The sentence "The two Arg-catabolising enzymes Arg1 and IDO1 reduce the hyperinflammation by an immunosuppressive effect via either Arg starvation (for Arg1) or via the immunoregulatory activity of the Arg-derived metabolites Kyn (for IDO1)." should read: "The two Arg- and Trp-catabolising enzymes Arg1 and IDO1 reduce the hyperinflammation by an immunosuppressive effect via either Arg starvation (for Arg1) or via the immunoregulatory activity of the Trp-derived metabolites Kyn (for IDO1)." The author apologizes for the mistake. The original article has been corrected.

\begin{abstract}
(c) (i)
Open Access This article is licensed under a Creative Commons Attribution 4.0 International License, which permits use, sharing, adaptation, distribution and reproduction in any medium or format, as long as you give appropriate credit to the original author(s) and the source, provide a link to the Creative Commons license, and indicate if changes were made. The images or other third party material in this article are included in the article's Creative Commons license, unless indicated otherwise in a credit line to the material. If material is not included in the article's Creative Commons license and your intended use is not permitted by statutory regulation or exceeds the permitted use, you will need to obtain permission directly from the copyright holder. To view a copy of this license, visit http://creativecommons. org/licenses/by/4.0/.
\end{abstract}

() The Author(s) 2021 